\title{
More pressures on Rothschild system
}

Geology project threatened by

\section{more cuts}

The Rothschild principle, whereby British government departments ("customers") commission research from research councils ("contractors"), already corrupted in medical and agricultural research, is now showing signs of strain elsewhere. The latest development is that two of the customers of the Natural Environment Research Council, the Department of the Environment and the Department of Industry, are threatening to cut the amount of geological research they are prepared to commission.

At stake are the Geological Survey and the mineral reconnaissance programme, both run by the council's Institute of Geological Sciences. The Department of the Environment, which currently contributes $£ 1.5$ million to the $£ 4.5$ million annual budget of the Geological Survey, is cutting its contribution to geological generally from $£ 3.5$ million in $1980-81$ to $£ 2.6$ million in 1981-82. Although the department has not yet specified its priorities, it is expected that the cuts will be made in the Geological Survey and the engineering geology and bulk minerals resources programmes. The Department of Industry, which is the sole supporter of the mineral reconnaissance programme, is threatening to cut that budget from about $£ 1.2$ million in $1980-81$ to $£ 0.8$ million in 1981-82.

Both departments say that they no longer want to fund research which is not directly relevant to their work. Thus the Department of the Environment will only fund those parts of the Geological Survey related to planning permission. Alternative funds for the survey are unlikely to be forthcoming and it will have to make do with less. Dr G. M. Brown, director of the Institute of Geological Sciences, finds his planning hampered by the Department of the Environment's delay in deciding its new priorities.

The Department of Industry is hoping that the mineral reconnaissance programme will find alternative funds from industry. Since 1972, this unit has been searching for metalliferous ores in Britain, especially in the Scottish Highlands, North Wales and Devon and Cornwall. Although deposits of several minerals - in particular copper and tungsten - have been found, only one, a barites deposit in Scotland, has led to an application for mining rights by private industry. Nevertheless, industry is interested. Companies consider that the results provide useful information for assessing mining profitability in the light of future market trends. But hitherto, there have been no direct commissions from industry.

The Natural Environment Research Council has been trying to establish whether it could act a contractor for private industry. Meetings with the mining houses have thrown up several problems such as that of confidentiality (reports have previously been publicly available) and the assignment of mining rights. Industry itself is keen that the programme should continue, but considers that financial support for it is properly the duty of central government.

Time is now running out. The new financial year begins in April, and twenty of the mineral reconnaissance staff have already moved to oil surveys of the North Sea, paid for by the Department of Energy. The Department of Industry has not finally decided to cut its support, but is thought by several observers to be in a mood to say that if private industry does not produce some cash, it will a sign that the programme has little practical relevance. Judy Redfearn

\section{Carter's last budget asks for more}

\section{Washington}

Determined to enter the history books on an optimistic note, the outgoing Carter Administration has proposed to Congress a budget for the next fiscal year that contains a 4.3 per cent real growth in support for basic research.

"This is the best budget for the past four years for science and engineering research", said Dr Frank Press, the President's Science Advisor and director of the Office of Science and Technology, commenting on the budget proposals last week. He added that it confirmed President Carter's commitment to the support of science and technology "as an investment in the future".

In addition to the intended growth above the expected level of inflation, Dr Press singled out several initiatives that were being proposed by the outgoing Administration "to solve problems that we have known about for a number of years".

One of these is the proposed inclusion in the budget of the National Science Foundation of a $\$ 75$ million fund to improve university research equipment and laboratories. Their rapidly deteriorating state was highlighted in a recent report from the Association of American universities.

Two other proposals involve traineeships and other awards to avoid potential manpower shortages in fields such as computer science and energy engineering, and efforts to meet the present difficulties of engineering schools where, according to Dr Press, "faculty and equipment are not on a par with what one would expect in industry".

The big question, of course, is how much of this increase will escape the rapidly sharpening budget knife of the incoming Administration of President Ronald Reagan. For many social welfare programmes, the writing is already on the wall, but for science and technology the signals are mixed.

On the one hand, Mr Reagan's budget director, Mr David Stockman, has been talking about the need to rewrite the Carter budget "from top to bottom". $\mathrm{Mr}$
Stockman has previously placed the National Aeronautics and Space Administration (NASA) among his "low priority" agencies which might absorb significant cuts. In the same vein, a group known as the National Tax Limitation Committee put out a report last week suggesting, for example, reduced spending on the Galileo mission to Jupiter - already being delayed a year by NASA because of delays with the launch vehicles - on its list of "expenditure control opportunities". The group is also raising questions about the appropriateness of government support for the space shuttle, and suggesting a re-examination of the future cost-benefit ratio.

At the same time, however, members of the various transition teams which have been established by the Reagan Administration to look at research and development programmes have been making optimistic noises, insisting that the new president is committed to the support of "science, technology and productivity'.

Part of the increase in defence spending supported by both the Carter and the Reagan Administrations, for example, is likely to have beneficial spin-offs for research support, particularly in areas where the large aerospace companies have a stake. "I have been looking in teacups for the past two months, and each time I look I see a different picture", said outgoing NASA director Dr Robert Frosch last week.

The details of the Carter budget proposals contain several proposed new scientific starts. The NASA budget, for example, contains funding for the development of the Venus Orbiting Imaging Radar - announced by President Carter shortly before the election - as well as a new Geological Applications Program (GAP) which will use remote sensing satellites to study geological resources which might contribute to the discovery of new oil and gas deposits.

Reflecting the delays in the space shuttle programme, the proposed commitment to start work on a fifth shuttle orbiter, the 